\title{
USABILITY TESTING PADA WEBSITE E-COMMERCE MENGGUNAKAN METODE SYSTEM USABILITY SCALE (SUS) (STUDI KASUS : UMKMBULELENG.COM)
}

\author{
Agus Aan Jiwa Permana \\ Prodi Manajemen Informatika (D3), Universitas Pendidikan Ganesha \\ Singaraja, Indonesia \\ e-mail: agus.aan@undiksha.ac.id
}

\begin{abstract}
Abstrak
Pengembangan perangkat lunak sangat bermanfaat untuk membantu di beberapa bidang. Salah satunya adalah bidang pemasaran. Dengan perkembangan internet, proses pemasaran sudah lumbrah dilakukan melalui online dengan beberapa metode jual beli yang dilakukan seperti cash on delivery (COD), bayar di muka, atau bayar barang saja dengan ongkos kurir dibayar setelah barang diterima. Pemasaran online memerlukan $E$ commerce untuk membantu menghubungkan pembeli dengan penjual. Seperti yang dilakukan oleh kelompok perajin di Singaraja, dengan alamat website yang dapat diakses pada http://umkmbuleleng.com. Website ini sudah online, namun perlu dilakukan uji terkait untuk mengetahui apakah user dapat dengan mudah menggunakan aplikasi secara efektif dan efisien. Hal ini dilakukan untuk mengetahui tingkat kepuasan pengguna. Sebelum produk di launching secara luas, perlu dilakukan proses pengujian ini. Metode yang digunakan untuk melakukan pengujian ini adalah System Usability Scale (SUS). Hasil pengujian diperoleh yaitu baik. Sehingga aplikasi yang dikembangkan untuk perajin secara umum sudah sesuai dengan harapan pengguna.
\end{abstract}

Kata kunci : E-commerce untuk UMKM, Pemasaran Produk Perajin, System Usability Scale

\begin{abstract}
Software development is very useful to help in several fields. One of them is the field of marketing. With the development of the internet, the marketing process is already done online through several buying and selling methods such as cash on delivery (COD), prepayment, or pay for goods at the courier cost paid after the goods are received. Online marketing requires E-commerce to help connect buyers with sellers. As was done by a group of artisans in Singaraja, with a website address that can be accessed at http://umkmbuleleng.com. This website is already online, but a related test needs to be done to find out whether users can easily use the application effectively and efficiently. This is done to determine the level of user satisfaction. Before the product is widely launched, this testing process needs to be done. The method used to carry out this test is the System Usability Scale (SUS). The test results obtained are good. So that applications developed for craftsmen in general are in accordance with user expectations.
\end{abstract}

Keywords : E-commerce for Small Micro Medium Enterprises, Marketing of Craft Products, System Usability Scale

\section{PENDAHULUAN}

Penggunaan internet di Indonesia untuk melakukan belanja online menduduki peringkat satu di dunia, berdasarkan data dari lembaga riset Merchant Machine asal Inggris. Tentu hal ini sangat fantantis dengan angka pertumbuhan mencapai $78 \%$ pada 2018 [1]. Hal ini menunjukkan masyarakat senang melakukan belanja 
online dengan angka mencapai Rp. 3.19 juta per orang. Kebanyakan mereka membelanjakan uangnya untuk membeli tiket pesawat dan memesan hotel, kemudian belanja produk pakaian dan alas kaki, kemudian yang populer ketiga adalah belanja produk kesehatan dan kecantikan. Generasi milenial sangat senang berbelanja online karena menurut mereka sangat simple dan praktis, tinggal pesan barang langsung datang. Proses transaksi barang dilakukan melalui sebuah perangkat yang bernama E-commerce. E-commerce adalah sebuah aplikasi online yang dapat digunakan untuk melakukan transaksi pembelian dan penjualan produk apapun sehingga saat ini E-commerce menjadi semacam toko online yang berisi katalog produk. Konsumen dapat melihat produk, membaca deskripsi produk, melakukan komunikasi langsung dengan penjual, melakukan penawaran harga, melakukan pemesanan, serta semua jenis transaksi yang dulu hanya dapat dilakukan di dunia nyata. Sekarang semua transaksi produk sudah dapat dilakukan secara online.

Dengan perkembangan E-commerce yang pesat sangat menjanjikan untuk penjualan produk lain. Salah satunya adalah produk kerajinan. Sebagai destinasi wisata, pulau Bali banyak memiliki jenis kerajinan yang berbahan murah seperti sampah, bahkan sampai yang berbahan baku mahal seperti produk kerajinan kayu dan kain. Salah satu kabupaten di Bali Utara yaitu Buleleng, memiliki produk kerajinan khas yang terbuat dari kayu berupa bokor dan mangkok yang pemasarannya masih terbatas di sekitar Bali saja. Padahal dengan pernyataan dari dinas kominfo Buleleng yang mengajak bagi para perajin industri kecil menengah untuk memasarkan produknya secara daring/online melalui internet dan E-commerce [2]. Namun demikian, banyak perajin yang mengalami permasalahan dalam menggunakan $E$ commerce. Melalui pantauan di lapangan dan wawancara langsung dengan perajin, masih banyak yang mengalami kesulitan dalam memasarkan produknya dengan $E$ commerce. Sehingga melalui program pengabdian, Undiksha melalui Program Kemitraan Masyarakat (PKM) melakukan program pelatihan menggunakan $E$ commerce kepada para perajin UMKM Buleleng.

[3] memberitakan bahwa Undiksha melakukan pelatihan E-commerce untuk memperluas pangsa pasar untuk para perajin UMKM. Hal ini merupakan landasan untuk melakukan pengujian aplikasi yang telah dibuat dan digunakan dalam seminar Program Kemitraan Masyarakat (PKM) yang berkerjasama dengan perajin di Buleleng. Aplikasi yang dikembangkan harus dapat menjadi solusi yang dapat digunakan secara baik oleh para perajin dan pembeli. Sehingga harus dilakukan pengujian lebih lanjut. Salah satu produk dari hasil pengabdian PKM ini adalah E-commerce. Tentu saja aplikasi yang dikembangkan harus dilakukan beberapa tahap pengujian seperti blackbox testing, alpha testing, kemudian lanjut ke beta testing. Sebelum produk yang dikembangkan benar-benar siap untuk digunakan secara luas harus dilakukan pengujian terkait dengan kepuasan dan keefektifan dari aplikasi yang dikembangkan.

Salah satu pengujian aplikasi terkait dengan hal tersebut, harus melalui Usability Testing (US). Pengujian ini dilakukan untuk mengetahui kepuasan pelanggan dalam menggunakan aplikasi, dapat mengakses aplikasi secara efektit, dapat menggunakan aplikasi secara efisien.

Tim pengembang sudah melakukan uji coba, namun belum cukup. Karena akan digunakan secara luas, aplikasi harus diujicobakan kepada user yang sesungguhnya untuk mendapatkan umpan balik [4].

Tim desain dan pengembang aplikasi akan mendapatkan banyak informasi saat pengguna menggunakan aplikasi secara langsung dan apabila terjadi masalah dapat segera diatasi.

Terdapat beberapa metode yang dapat digunakan untuk melakukan ujicoba ini. Salah satunya adalah dengan menggunakan System Usability Scale (SUS). Metode ini paling banyak digunakan untuk melakukan uji software karena mudah untuk digunakan dan hasilnya dapat digunakan sebagai pertimbangan. Adapun alasan menggunakan metode ini karena 
sangat mudah dimengerti dan dalam implementasinya sangat mudah untuk digunakan sehingga metode ini popular digunakan dalam melakukan uji Usability Testing.

\section{METODE \\ Metode Penelitian}

Metode penelitian ini adalah deskriptif kuantitatif. Metode penelitian deskriptif adalah mendeskripsikan fenomenafenomena yang ada, baik fenomena alamiah maupun fenomena buatan manusia. Fenomena adalah berupa bentuk, aktivitas, karakteristik, perubahan, hubungan, kesamaan, dan perbedaan antara fenomena satu dengan lainnya [5]. Penelitian kuantitatif adalah penelitian dengan memperoleh data yang berbentuk angka atau data kualitatif yang diangkakan [6]. Metode penelitian kuantitatif merupakan suatu cara yang digunakan untuk menjawab masalah penelitian terkait dengan data berupa angka dan program statistik. Dalam proses pengumpulan datanya, dapat menggunakan instrumen penelitian.

Berkaitan dengan instrumen penelitian, terdapat tiga kemungkian yang digunakan oleh peneliti yaitu (1) peneliti menggunakan instrumen penelitian yang sudah baku yang sudah teruji/memenuhi persyaratan uji validitas dan reliabilitas. (2) Peneliti memodifikasi instrumen penelitian yang sudah ada sebelumnya, (3) peneliti mengembangkan sendiri instrumen yang akan digunakan untuk mengumpulkan data penelitian [7].

\section{Metode Pengumpulan Data}

Proses pengumpulan data dilakukan selama 3 bulan dari Agustus-Oktober 2019 setelah pengembangan website ecommerce selesai dikembangkan. Proses selanjutnya setelah pengembangan adalah pengujian. Angket yang digunakan adalah angket yang sudah valid, khusus untuk melakukan pengujian SUS. Kuisioner ini dapat diunduh langsung pada website resmi secara online.
Proses penyebaran kuisioner dibantu oleh beberapa oleh tim.

Pada proses pengujian ini angket diberikan kepada responden dari berbagai berbagai kalangan terutama remaja, anakanak kuliah, ibu rumah tangga, dan dewasa. Pengambilan data dilakukan dengan metode menjawab kuisioner yang sudah standar yang digunakan untuk metode SUS. Kuisioner disebarkan ke 20 orang responden untuk mengisi langsung kuisioner yang dipilih dengan cara random.

\section{Pengembangan Website}

Dalam proses pengembangan aplikasi, terdapat beberapa tahapan yang dilakukan antara lain Komunikasi, Perencanaan, Modelling, Implementasi, dan Deployment. Model yang digunakan adalah Waterfall. Adapun metode ini memiliki beberapa tahapan seperti namanya yang dapat dilihat seperti Gambar 1. Waterfall yang merupakan metode dengan pendekatan klasik, pendekatan sekuensial dengan urutan yang jelas[8].

Adapun tahapan pada metode ini yaitu Terdapat proses komunikasi, planning, pemodelan, implementasi, dan deployment. Setelah website dapat diimplementasikan, selanjutnya adalah memasukkan data riil. Data yang digunakan dalam website berasal asli dari para perajin UMKM Buleleng terkait dengan harga dan deskripsi produk.

\section{E-commerce UMKM Buleleng}

E-commerce adalah proses yang dilakukan konsumen dalam membeli dan menjual berbagai produk secara elektronik dari perusahaan ke perusahaan lain dengan menggunakan komputer sebagai perantara dalam transaksi bisnis. Menurut [9] E-commerce dibedakan menjadi beberapa jenis berdasarkan karakteristiknya yaitu :

- Business to Business (B2B)

- Business to Customer (B2C)

- Customer to Customer (C2C) 


\section{- Customer to Business (C2B)}

Sesuai dengan harapan, website perajin buleleng dapat diakses pada alamat http://umkmbuleleng.com.

Web ini dikembangkan untuk membantu para perajin menjual produk kerajinannya utuk market yang lebih luas lagi. Bukan sekedar di Singaraja saja. Perajin perlu memasarkan produknya lebih luas lagi untuk dapat bersaing dengan produk nasional maupun internasional. Dengan pemasaran produk yang luas, impact nya akan jelas dirasakan perajin.
Apabila saat ini perajin masih bertahan dengan penjualan offline saja maka ditakutkan pangsa pasar akan redup dan semakin lama dapat hilang karena banyak produk sejenis yang muncul. Sehingga proses penjualan perlu dibantu dengan teknologi informasi.

Proses pengembangan website dilakukan dalam beberapa tahapan yaitu komunikasi, perencanaan, dan desain. Desain aplikasi meliputi layout dari tampilan web itu sendiri. Adapun beberapa bagian dari website seperti halaman utama dapat dilihat seperti Gambar 2.

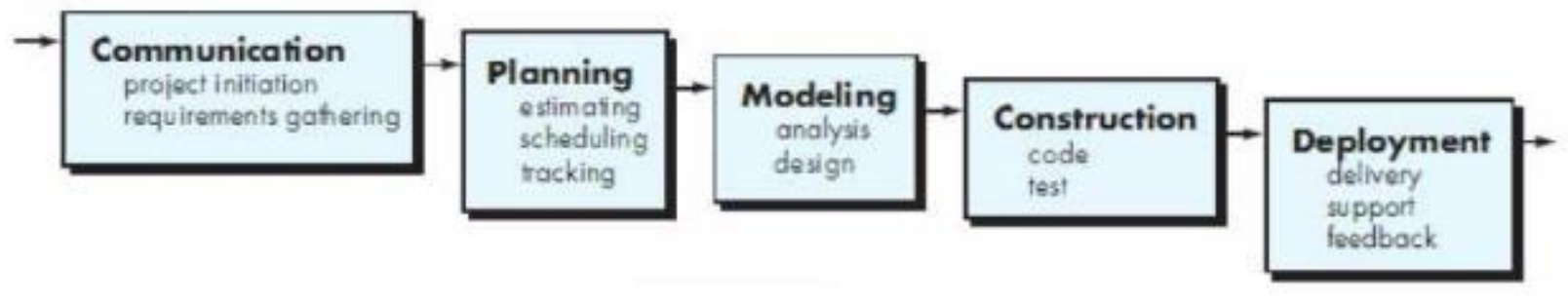

Gambar 1. Metode Waterfall

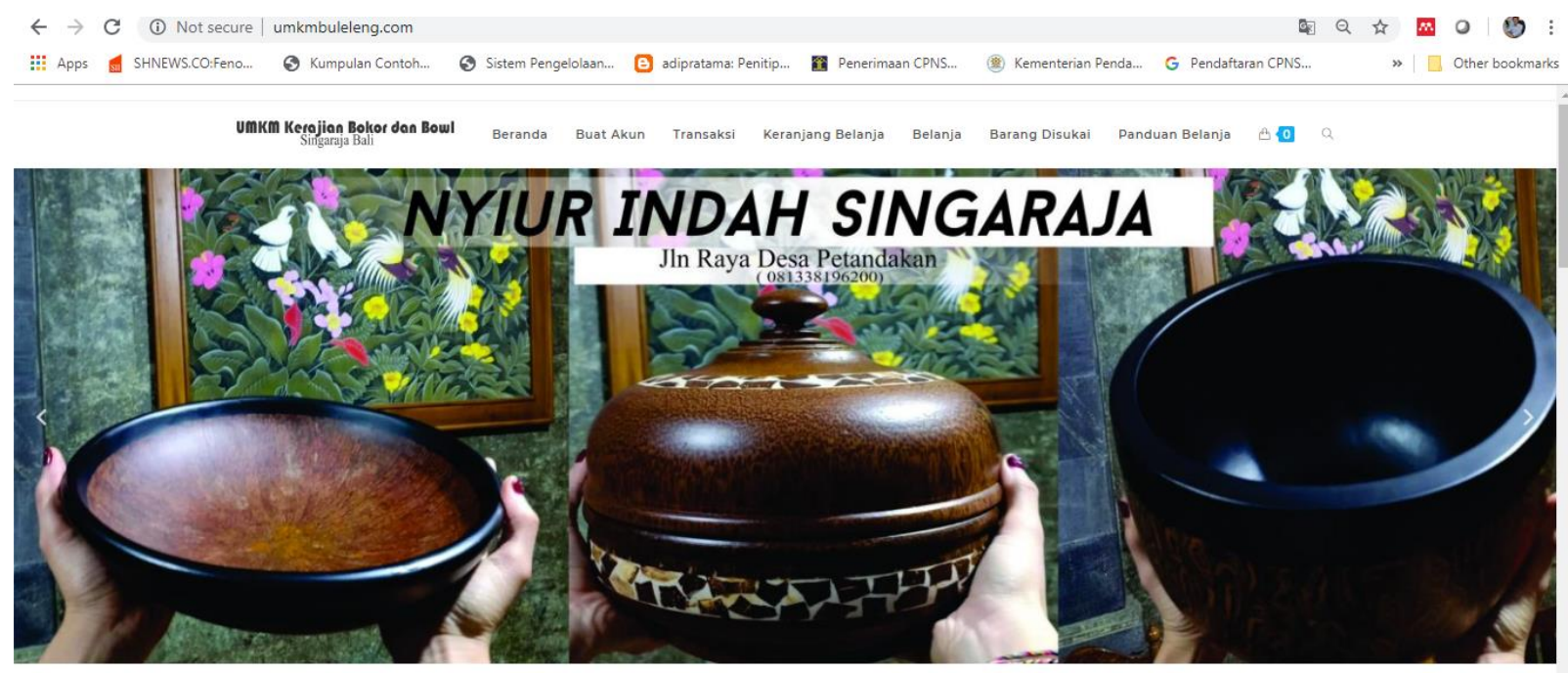

PRODUK TERBARU

Gambar 2. Website UMKM Buleleng

Selanjutnya untuk produk, pada website tersebut berisi beberapa produk yang ditawarkan yang dapat dilihat langsung seperti Gambar 3. Produk yang dijual adalah hasil kerajinan kayu dari UMKM buleleng seperti Bokor, Dulang, Cangkir, Piring, Mangkuk, Suvenir dan lainnya yang bahannya semuanya terbuat dari kayu.

Proses transaksi pembelian yang dilakukan adalah dengan menambahkan barang yang di beli ke keranjang belanja seperti Gambar 4. Pengguna harus membuat akun terlebih dahulu untuk 
memudahkan dalam proses transaksi terkait dengan pembayaran. Saat proses transaksi berlangsung, pengguna mengisi data, alamat barang diterima, melihat detail order.

Pengguna disediakan panduan untuk dapat menggunakan sistem dengan baik dan benar dengan membaca petunjuk terlebih dahulu. Adapun panduan pengguna dapat dilihat seperti pada Gambar 5 dengan memilih menu panduan belanja. Panduan ini berisikan instruksi tata cara untuk melakukan transaksi melalui sistem E-commerce umkm buleleng.com.

\section{Komponen E-commerce}

Terdapat beberapa kelebihan yang dimiliki oleh E-commerce yang tidak dimiliki oleh transaksi bisnis offline [10] yaitu :

- Produk : banyak produk yang dapat dipasarkan dan dijual di internet

- Hosting-Domain : hosting adalah sama halnya dengan tempat/lapak dari penjual yang dalam internet disebut dengan hosting. Kemudian setelah memiliki tempat, ruko atau kios biasanya diberikan sebuah nama. Nama inilah yang di internet dikenal dengan istilah domain

- Pemesanan produk : terdapat banyak cara yang digunakan dalam menerima pesanan seperti email, telepon, whatsapp, chating dan voice serta video call.

- Cara pembayaran : proses pembayaran dalam aplikasi E-commerce beragam dari menggunakan kartu kredit, paypal, ATM, atau dengan dengan bayar di tempat (cash on delivery)

- Metode pengiriman : proses pengiriman barang dapat melibat kurir atau pihak ketiga seperti JNE, POS, J\&T, baik mengunakan transportasi darat dan udara tergantung kesepakatan

- Kustomer servis : dalam proses ini dapat menggunakan email, contact us, telepon, chat dan lainnya yang disediakan oleh aplikasi.

\section{PRODUK TERBARU}
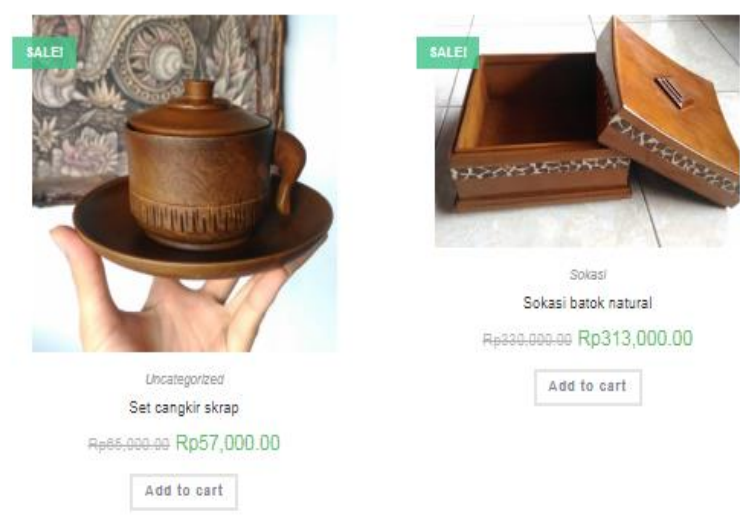

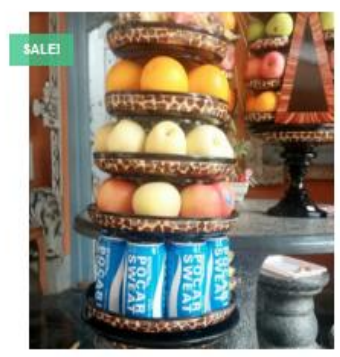

Dularg, Dulang Susun

Dulang suaun bus tas

Re4t800000 Rp467.000.00 Add to cart
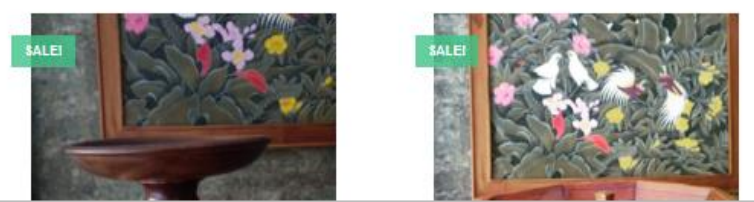

Gambar 3. Produk yang ditawarkan 
UmKm Kerojian Bokor don Bowl Beranda Buat Akun Transaksi Keranjang Belanja Belanja Barang Disukai Panduan Belanja $\quad 10$

Keranjang Belanja

Aิ > Keranjang Belanja

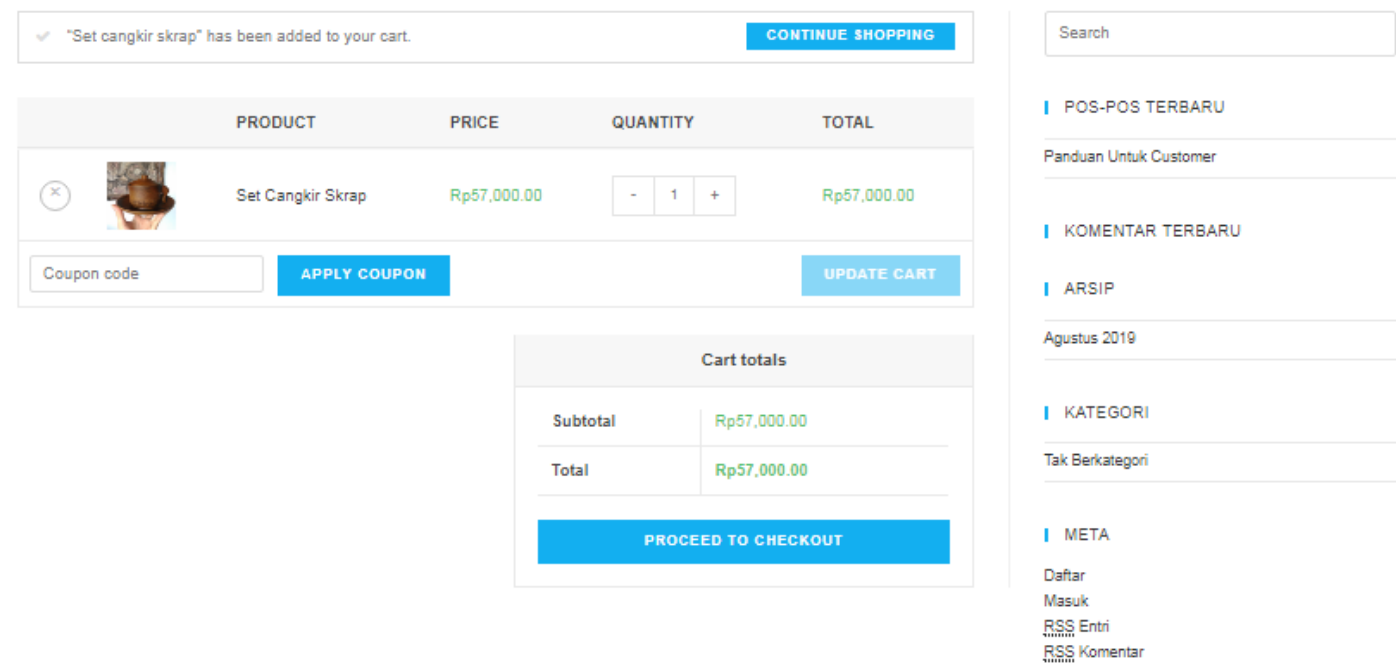

Gambar 4. Proses Transaksi

UmKm Kerojian Bokor dan Bowl Beranda Buat Akun Transaksi Keranjang Belanja Belanja Barang Disukai Panduan Belanja $\quad 1 \quad$ Q

\section{Blog}

A $>2019>$ Agustus > $13>$ Tak Berkategori > Panduan Untuk Customer

\section{Panduan Untuk Customer}

\& dewra - 13 Aguttus $2019-\square$ Tak Berkategon - $\bigcirc 0$ comments

USER GUIDE CUSTOMER ( Pelanggan )

1. CARA LOGIN

1. Pertama, Cari halaman My Account login terlebih dahulu sebelum anda memesan barang. Apabila belum mempunyai akun buat akun baru dengan memasukkan e-mail anda di menu register.

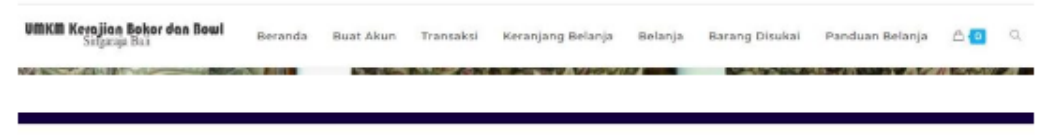

\section{Login Register}

Search

I POS-POS TERBARU

Panduan Untuk Customer

I KOMENTAR TERBARU

I ARSIP

Agustus 2018

I KATEGORI

Tak Berkategori

I META

Daftar

Masuk

RSS Entri

RSS Komentar

Gambar 5. Panduan Customer 


\section{Proses Transaksi E-commerce}

[11] menyatakan bahwa, dalam proses transaksi E-commerce sudah semakin aman dan dilengkapi dengan jaminan keamanan barang sampai di tempat seperti pada ilustrasi Gambar 6 . Beberapa proses dalam pembelian barang melalui E-commerce yaitu :

1. Konsumen memesan produk melalui $E$ commerce, konsumen dapat meninjau ulang terhadap produk yang ditawarkan dan melakukan perbandingan harga dan kualitas

2. E-commerce mengkonfirmasi bahwa ada rencana pemesanan dari konsumen melalui keranjang belanja, hal ini membantu persiapan ketika transaksi disepakati maka pesanan dapat langsung dikirim

3. Konsumen melakukan transfer, proses ini dapat dilakukan ketika sudah deal antara pembeli dengan penjual

4. Konfirmasi pembayaran dari Bank, dalam tahap ini setelah dilakukan trasfer ke akun bank E-commerce maka pihak $E$ commerce memberikan konfirmasi dan perintah untuk mengirimkan barangnya.

5. E-commerce memberikan konfirmasi dan perintah untuk segera mengirimkan barang yang dipesan, perintah ini disampaikan oleh pihak E-commerce dan apabila pengiriman terlambat melakukan pengiriman maka uang akan ditransfer kembali ke konsumen

6. Proses pengiriman oleh pedagang, proses selanjutnya adalah melakukan pembuatan produk sesuai pesanan dan mengirimkan ke pemesan melalui proses packing yang benar dan aman. Apabila menggunakan pihak ekspedisi, silahkan pilih yang sudah terbukti aman dan bertanggung jawab.

7. Proses pengiriman barang oleh ekspedisi, pihak ketiga ini khusus mengirim barang pesanan kepada kustomer dan memastikan barang sampai dengan keadaan yang aman.

8. Penyerahan barang, barang akan diantarkan ekspedisi kepada pembeli sekaligus memberikan konfirmasi secara tersistem bahwa produk sudah sampai.

9. Konfirmasi produk sudah diterima konsumen, setelah produk diterima konsumen, selanjutnya akan dilakukan pengecekan barang dan pemberian rating atau feedback terhadap produk yang diterima apakah sesuai atau tidak (biasanya dalam bentuk tanda bintang)

10. Pencairan dana oleh Bank, pihak Ecommerce meminta bank untuk mencairkan dana kepada penjual melalui akun E-commerce. Apabila penilaian konsumen buruk, maka dana dapat saja tidak dicairkan.

11. Akses pencarian dana kepada pedagang online, proses ini merupakan proses teriakhir dari transaksi. Biasanya berlangsung selama tiga hari dari proses pemesanan awal. Penjual akan ditrasfer uang ke rekeningnya oleh pihak $E$ commerce sesuai dengan harga penjualan dan biaya pengirimannya.

\section{Metode System Usability Scale (SUS)}

Proses pengukuran kegunaan mencakup tiga kata yang terkait dengan efektivitas, efisiensi, dan kepuasan [12]. Sehingga setiap upaya untuk mengevaluasi kegunaan dari sebuah produk harus dibuat sesuai dengan setidaknya tiga parameter ini. Salah satu metode yang dapat digunakan untuk menguji usability adalah SUS. Metode ini dapat digunakan untuk melakukan pengujian teknologi yang independen baik pada perangkat keras, lunak, website, bahkan perangkat seluler (Sauro, 2011 dalam [5]). Terdapat melakukan pengujian SUS memiliki sepuluh instrument pertanyaan.

Setiap pertanyaan memiliki skor 1-5. Apabila sangat tidak setuju dapat memilih (1) dan sangat setuju dengan memilih (5). 
Terdapat aturan untuk 10 pertanyaan yang ada yaitu setiap pertanyaan dengan nomor ganjil maka jawaban dari responden (Skor jawaban responden - 1). Setiap pertanyaan dengan nomor genap, maka jawaban responden (5 - Skor jawaban responden). Kemudian jumlahkan skor per responden (Jumlah Skor Responden $\mathrm{x}$ 2.5). Setelah semua skor responden dikalikan dengan 2.5 selanjutnya dijumlahkan dan dibagi jumlah responden semuanya.

\section{HASIL DAN PEMBAHASAN}

Jumlah responden yang mengisi kuisioner sebanyak 20 Orang. Dengan perhitungan menggunakan rumus SUS diperoleh hasil seperti pada Tabel 1 . Berdasarkan Tabel 1 diperoleh nilai sebesar 72. Nilai tersebut berarti masuk dalam kategori Baik sesuai dengan Gambar 7. Baik dalam hal ini adalah dalam hal usability sistem.

Sehingga e-commerce yang dikembangkan sudah sesuai dengan harapan pengguna dan layak untuk digunakan dan diakses secara lebih luas lagi. Pengembangan selanjutnya adalah menambah data serta mempromosikan kepada masyarakat umum melalui sosial media, radio, dan youtube untuk mengakses layanan sehingga dapat membantu para perajin dalam mempromosikan dan menjual produknya.

Tabel 1. Perhitungan dengan metode SUS

\begin{tabular}{|c|c|c|c|c|c|c|c|c|c|c|c|c|c|c|c|c|c|c|c|c|c|c|}
\hline \multirow[b]{2}{*}{ No } & \multicolumn{10}{|c|}{ Skor Responden } & \multicolumn{10}{|c|}{ Skor Hasil Hitung SUS } & \multirow[b]{2}{*}{ JML } & \multirow{2}{*}{$\begin{array}{c}\text { Nilai } \\
\text { (Jumlah } \\
\text { x 2.5) }\end{array}$} \\
\hline & $\begin{array}{l}Q \\
1\end{array}$ & $\begin{array}{l}\mathbf{Q} \\
2\end{array}$ & $\begin{array}{l}\mathbf{Q} \\
\mathbf{3}\end{array}$ & $\begin{array}{l}Q \\
4\end{array}$ & $\begin{array}{l}Q \\
5\end{array}$ & $\begin{array}{l}Q \\
6\end{array}$ & $\begin{array}{l}Q \\
7\end{array}$ & $\begin{array}{l}Q \\
8\end{array}$ & $\begin{array}{l}Q \\
9\end{array}$ & $\begin{array}{c}Q \\
10\end{array}$ & $\begin{array}{l}Q \\
1\end{array}$ & $\begin{array}{l}\mathbf{Q} \\
2\end{array}$ & $\begin{array}{l}Q \\
3\end{array}$ & $\begin{array}{l}Q \\
4\end{array}$ & $\begin{array}{l}Q \\
5\end{array}$ & $\begin{array}{l}Q \\
6\end{array}$ & $\begin{array}{l}Q \\
7\end{array}$ & $\begin{array}{l}Q \\
8\end{array}$ & $\begin{array}{l}Q \\
9\end{array}$ & $\begin{array}{c}Q \\
10\end{array}$ & & \\
\hline 1 & 3 & 4 & 4 & 2 & 4 & 3 & 4 & 2 & 4 & 3 & 2 & 1 & 3 & 3 & 3 & 2 & 3 & 3 & 3 & 2 & 25 & 63 \\
\hline 2 & 3 & 2 & 4 & 2 & 3 & 3 & 4 & 2 & 4 & 2 & 2 & 3 & 3 & 3 & 2 & 2 & 3 & 3 & 3 & 3 & 27 & 68 \\
\hline 3 & 3 & 2 & 4 & 2 & 4 & 2 & 4 & 2 & 3 & 2 & 2 & 3 & 3 & 3 & 3 & 3 & 3 & 3 & 2 & 3 & 28 & 70 \\
\hline 4 & 4 & 2 & 4 & 2 & 5 & 1 & 4 & 1 & 5 & 2 & 3 & 3 & 3 & 3 & 4 & 4 & 3 & 4 & 4 & 3 & 34 & 85 \\
\hline 5 & 4 & 2 & 4 & 2 & 4 & 3 & 4 & 2 & 4 & 3 & 3 & 3 & 3 & 3 & 3 & 2 & 3 & 3 & 3 & 2 & 28 & 70 \\
\hline 6 & 4 & 4 & 3 & 4 & 3 & 5 & 3 & 4 & 4 & 4 & 3 & 1 & 2 & 1 & 2 & 0 & 2 & 1 & 3 & 1 & 16 & 40 \\
\hline 7 & 4 & 3 & 5 & 1 & 4 & 1 & 4 & 1 & 4 & 3 & 3 & 2 & 4 & 4 & 3 & 4 & 3 & 4 & 3 & 2 & 32 & 80 \\
\hline 8 & 4 & 3 & 5 & 1 & 4 & 1 & 4 & 1 & 4 & 3 & 3 & 2 & 4 & 4 & 3 & 4 & 3 & 4 & 3 & 2 & 32 & 80 \\
\hline 9 & 4 & 1 & 5 & 1 & 5 & 1 & 5 & 1 & 5 & 5 & 3 & 4 & 4 & 4 & 4 & 4 & 4 & 4 & 4 & 0 & 35 & 88 \\
\hline 10 & 4 & 3 & 5 & 2 & 4 & 2 & 4 & 2 & 4 & 3 & 3 & 2 & 4 & 3 & 3 & 3 & 3 & 3 & 3 & 2 & 29 & 73 \\
\hline 11 & 4 & 2 & 3 & 3 & 4 & 2 & 3 & 2 & 3 & 3 & 3 & 3 & 2 & 2 & 3 & 3 & 2 & 3 & 2 & 2 & 25 & 63 \\
\hline 12 & 3 & 3 & 4 & 1 & 4 & 1 & 4 & 1 & 1 & 4 & 2 & 2 & 3 & 4 & 3 & 4 & 3 & 4 & 0 & 1 & 26 & 65 \\
\hline 13 & 3 & 2 & 4 & 1 & 3 & 1 & 4 & 2 & 3 & 3 & 2 & 3 & 3 & 4 & 2 & 4 & 3 & 3 & 2 & 2 & 28 & 70 \\
\hline 14 & 4 & 2 & 4 & 4 & 4 & 2 & 4 & 1 & 4 & 4 & 3 & 3 & 3 & 1 & 3 & 3 & 3 & 4 & 3 & 1 & 27 & 68 \\
\hline 15 & 3 & 3 & 4 & 3 & 4 & 2 & 4 & 2 & 3 & 1 & 2 & 2 & 3 & 2 & 3 & 3 & 3 & 3 & 2 & 4 & 27 & 68 \\
\hline 16 & 4 & 3 & 4 & 3 & 4 & 3 & 4 & 3 & 4 & 3 & 3 & 2 & 3 & 2 & 3 & 2 & 3 & 2 & 3 & 2 & 25 & 63 \\
\hline 17 & 4 & 1 & 4 & 1 & 3 & 1 & 3 & 1 & 4 & 2 & 3 & 4 & 3 & 4 & 2 & 4 & 2 & 4 & 3 & 3 & 32 & 80 \\
\hline 18 & 4 & 3 & 5 & 1 & 4 & 1 & 4 & 1 & 4 & 3 & 3 & 2 & 4 & 4 & 3 & 4 & 3 & 4 & 3 & 2 & 32 & 80 \\
\hline 19 & 4 & 3 & 5 & 2 & 4 & 2 & 4 & 2 & 4 & 3 & 3 & 2 & 4 & 3 & 3 & 3 & 3 & 3 & 3 & 2 & 29 & 73 \\
\hline 20 & 4 & 1 & 5 & 1 & 5 & 1 & 5 & 1 & 5 & 5 & 3 & 4 & 4 & 4 & 4 & 4 & 4 & 4 & 4 & 0 & 35 & 88 \\
\hline \multicolumn{22}{|c|}{ Skor rata-rata (Hasil Akhir) } & 72 \\
\hline & & & & & & & & & & era & $1 \mathrm{He}$ & & & & & & & & & & & GOOD \\
\hline
\end{tabular}




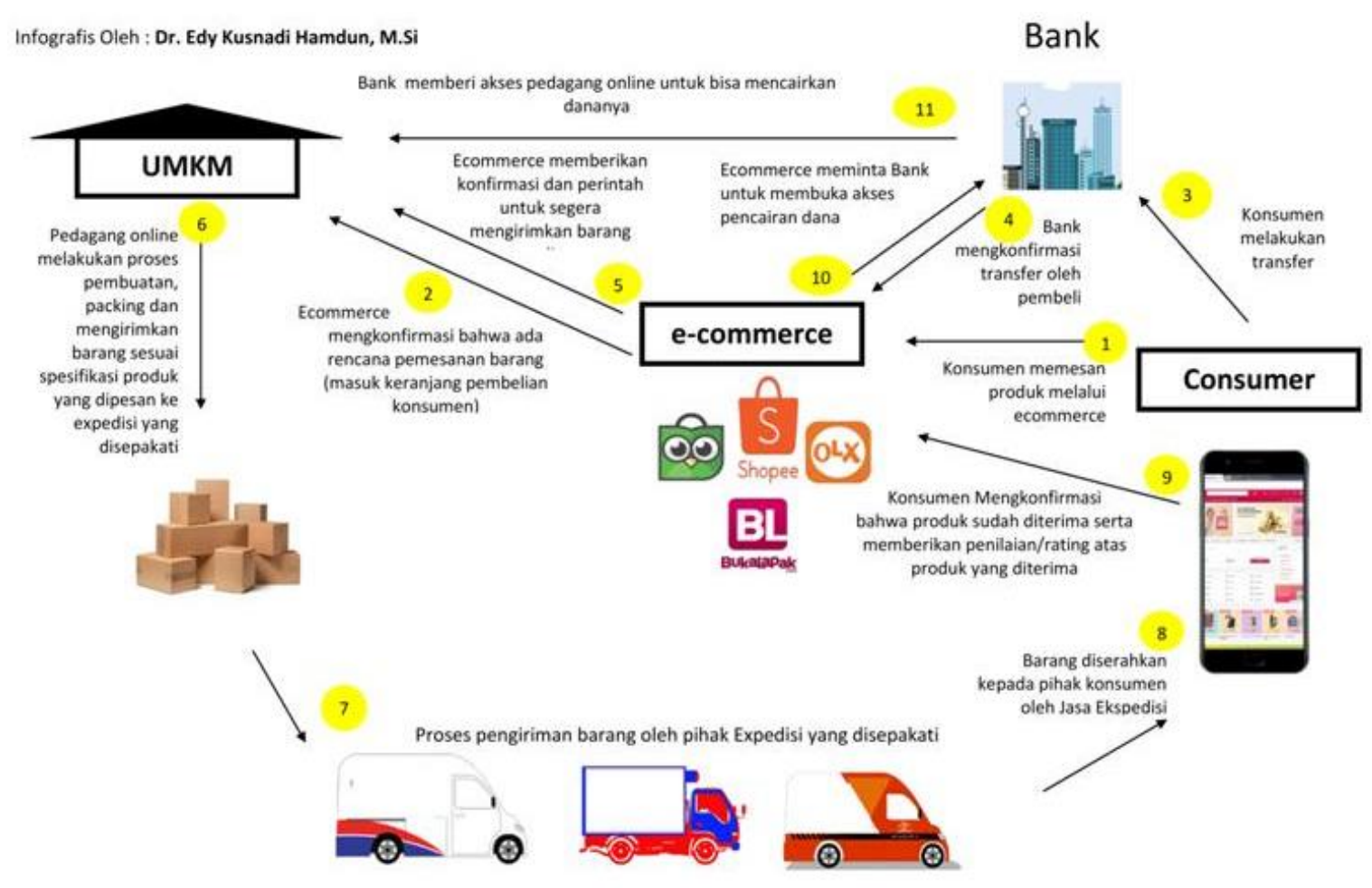

Gambar 6. Proses Transaksi E-Commerce

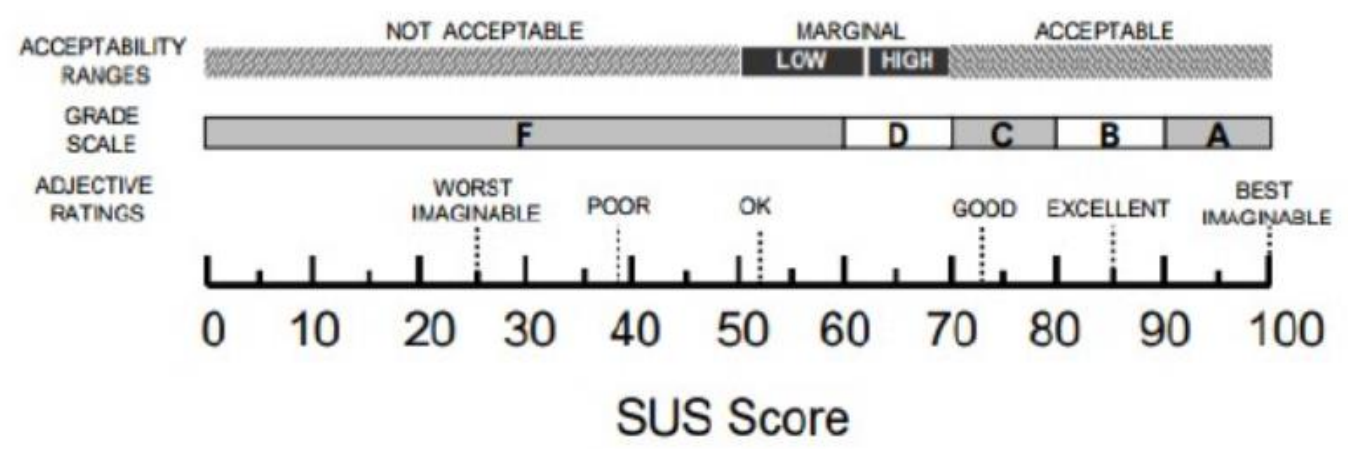

Gambar 7. Rentangan Nilai SUS

\section{SIMPULAN}

Berdasarkan permasalah yang sedang dihadapi dalam melakukan Usability Testing terhadap produk website E-commerce perajin UMKM Buleleng menghasilkan penilaian yang positif. Penilain yang diperoleh sebesar 72 yang masuk dalam kategori Baik. Secara umum berarti website ini sudah layak untuk digunakan untuk melakukan jual beli produk kerajinan yang dibuat oleh para perajin di Buleleng. Perlu dilakukan beberapa perbaikan lagi seperti penambahan konten, dan kejelasan aturan untuk melakukan transaksi sehingga memudahkan proses transaksi elektronik.

\section{UCAPAN TERIMAKASIH}

Ucapan terimakasih ditujukan kepada RISTEKDIKTI melalui Universitas Pendidikan Ganesha yang telah memberikan pendanaan untuk pelaksanaan Program Kemitraan Masyarakat (PKM) 2019 yang dilaksanakan selama 1 Tahun. 


\section{DAFTAR PUSTAKA}

[1] H. Widowati, "Indonesia Jadi Negara dengan Pertumbuhan E-Commerce Tercepat di Dunia," databoks, 2019.

[2] I. K. Suparta, "Buleleng ajak perajin pasarkan produk lewat E-Commerce," no. September 2018, pp. 1-18, 2019.

[3] E. M. Yakub, "Undiksha latih UMKM Buleleng perluas pasar secara digital," pp. 1-17, 2019.

[4] Binus, "Kenal Dekat Dengan Usability Testing," pp. 1-5, 2019.

[5] U. Ependi and F. Panjaitan, "System Usability Scale Antarmuka Palembang Guide Sebagai Media Pendukung Asian Games XVIII," vol. 3, no. 2, 2018.

[6] Widisudharta, "Metodelogi penelitian," pp. 1-5, 2019.

[7] Wahidmurni, "Pemaparan Metode Penelitian Kuantitatif," pp. 1-16, 2017.

[8] R. S. Pressman, Software Engineering. McGraw-Hill, 2010.
[9] I. Sandra, Y. Saputri, M. Fadhli, and I. Surya, "Penerapan Metode UCD ( User Centered Design ) pada E-Commerce Putri Intan Shop Berbasis Web," vol. 2, pp. 269-278, 2017.

[10] S. M. Maulana, Heru Susilo, and Riyadi, "Implementasi E-Commerce Sebagai Media Penjualan Online (Studi Kasus Pada Toko Pastbrik Kota Malang)," J. Adm. Bisnis (JAB, vol. 29, no. 1, 2015.

[11] F. UNARS, "Berkembanganya Proses Transaksi Ecommerce Indonesia," pp. 1-42, 2017.

[12] V. Peppa, S. Lysikatos, and G. Metaxas, "Human-computer interaction and usability testing: application adoption on B2C Web sites," vol. 14, no. 1, pp. 112-118, 2012. 